\title{
Consumers' and Farmers' Perceptions in Europe Regarding the Use of Composted Bedding Material from Cattle
}

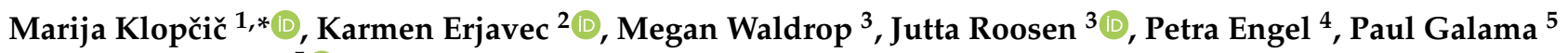 \\ and Abele Kuipers 5 (D) \\ 1 Department of Animal Science, Biotechnical Faculty, University of Ljubljana, SI-1230 Domžale, Slovenia \\ 2 Faculty of Economics and Informatics, University of Novo Mesto, SI-8000 Novo Mesto, Slovenia; \\ Karmen.Erjavec@gmail.com \\ 3 TUM School of Management, Technical University of Munich, DE-85354 Freising, Germany; \\ megan.waldrop@tum.de (M.W.); jroosen@tum.de (J.R.) \\ 4 Institut für Tierzüchtung, Justus-Liebig Universität Gießen, DE-35390 Gießen, Germany; \\ Petra.Engel@agrar.uni-giessen.de \\ 5 Livestock Research, Wageningen University \& Research, NL-6708 WD Wageningen, The Netherlands; \\ Paul.Galama@wur.nl (P.G.); Abele.Kuipers@wur.nl (A.K.) \\ * Correspondence: Marija.Klopcic@bf.uni-lj.si; Tel.: +386-41-546-484
}

Citation: Klopčič, M.; Erjavec, K.; Waldrop, M.; Roosen, J.; Engel, P.; Galama, P.; Kuipers, A. Consumers and Farmers' Perceptions in Europe Regarding the Use of Composted Bedding Material from Cattle. Sustainability 2021, 13, 5128. https:// doi.org/10.3390/su13095128

Academic Editor: Antoni Sánchez

Received: 6 April 2021

Accepted: 29 April 2021

Published: 3 May 2021

Publisher's Note: MDPI stays neutral with regard to jurisdictional claims in published maps and institutional affiliations.

Copyright: (C) 2021 by the authors Licensee MDPI, Basel, Switzerland. This article is an open access article distributed under the terms and conditions of the Creative Commons Attribution (CC BY) license (https:// creativecommons.org/licenses/by/ $4.0 /)$.
Abstract: By-products like sawdust and straw are applied in compost bedded-pack barns (CBP) for cattle. These materials, which are gradually mixed with excreta and undergo a composting process, serve as a lying bed for the cattle. This study aims to assess the perception of consumers and farmers regarding the use of $\mathrm{CBP}$ during the grazing season of cattle for raising other animals or for growing food crops. This was examined by combining surveys with consumers from eight European countries and cattle farmers, focus groups with consumers, and in-depth interviews with individual farmers who implemented alternative uses of compost. The results showed that farmers preferred the compost bedded-pack system to the cubicle system in terms of sustainability and market aspects, although the cost of the bedding material required for CBP was seen as a significant negative aspect. Around half of all consumers indicated that the compost can be used for non-edible products and $26 \%$ indicated the compost can be used for raising other animals. Furthermore, $5 \%$ of consumers felt that compost should not be used for any other purpose. There were statistically significant differences between countries; therefore, regional specificities should be taken into account when marketing products from compost in CBP barns.

Keywords: composting material; cattle housing; alternative use; produce; circular economy; marketing; farmer and consumer; perceptions

\section{Introduction}

Public concern about food safety and the impacts of agriculture on the environment focuses on the appropriate use and efficient recycling of animal manure, particularly in regions with high animal density [1-3]. Animal manure, including urine, is a main source worldwide of fertilizer for agricultural soil. However, $86 \%$ to $93.3 \%$ [4] of the ammonia $\left(\mathrm{NH}_{3}\right)$ emissions in Europe are caused by agricultural activities [5]. Moreover, foodborne pathogens such as Escherichia coli O157:H7, Salmonella, and Listeria monocytogenes can survive in the soil for several months following the manure application [6-9] and contaminate the vegetables grown in the soil fertilized with manure $[10,11]$. This has prompted governments, agricultural advisors, developers of treatment technologies from industry, researchers, and livestock farmers to develop and apply strategies, technologies, and practices as a means to mitigate the environmental and food safety risks from livestock operations.

Composting is one of the most widely used environment-friendly practices of livestock manure and results in valuable organic products [12-14]. Composted animal manure con- 
tributes positively to soil quality $[15,16]$, soil fertility [17-19] and the environment $[20,21]$ in addition to being considered an attractive waste management option. However, it requires proper treatment, storage, and application in order to avoid pollution threats, such as ammonia and greenhouse gas emission into the atmosphere, nitrate leaching into groundwater, and phosphorous runoff into surface waters [13,16,22]. Composting also appears to be an effective way to minimize pathogenic counts in animal manure. Properly composted manure that optimizes the carbon-to-nitrogen ratios, temperature, and moisture levels can reduce or eliminate bacterial pathogens present in animal manure to levels recommended by regulatory agencies and be efficiently used as a biological soil amendment to grow fruits and vegetables [23]. The survival of E. coli O157 in compost heaps reached almost undetectable levels in less than two weeks when the compost piles were turned [24].

One of the advanced sustainable uses of compost is from the compost bedded-pack barns (CBP), generally known as compost barns or freewalk barns (Figure 1). CBP was initially developed in Israel and the USA and spread with some modification to Europe in the last decade. The system allows cows more freedom to move than conventional tie-stalls and cubicle barns (free stalls), since it provides, when properly managed, a dry, comfortable, and healthy surface on which cows lie, stand, and walk $[25,26]$. CBP is composed of a large bedded-pack resting area that is aerated at least once a day, separated from a feed alley by a 1.2-m high concrete wall [27] (see Figure 1). CBP is applied with a completely free walking and lying area as an innovative housing system. The composting process in the barn requires the input of oxygen into the bedded-pack. This is achieved by cultivating the bedded-pack one to three times daily (see Figure 2). Additional stimulation of the composting process is done, especially in the Netherlands, by mechanically aerating the bedded-pack. Pipes are installed in the floor below the lying area, which aerate the beddedpack by either sucking or pushing the air through the bedded-pack. The temperature of the composing bedded-pack at $20 \mathrm{~cm}$ deep is typically between 20 to 50 degrees Celsius.

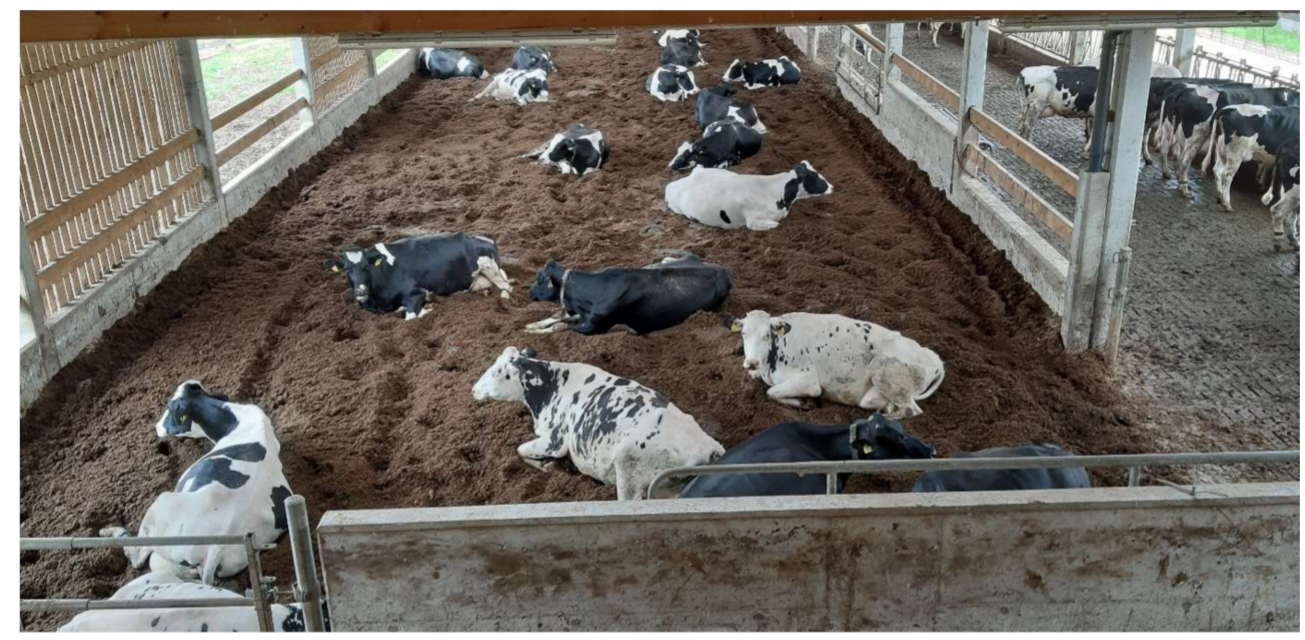

Figure 1. Compost bedded-pack barn for dairy cows (CBP).

Besides reduce and recycle, reuse is one of the key Rs of the "three Rs" of sustainability (Reduce-Reuse-Recycle). As CBP is a sustainable and food-safe livestock manure practice $[13,25]$, the question arises of what its reuse (i.e., an alternative use to bedding for cows) can be. There are only a few ideas and practices regarding the reuse of compost from CBPs. One major potential for the empty barn with the compost material during the grazing period (typically spring to fall) is to raise pigs or chickens $[25,28]$. Other options are to use the resting area of the CBP for the production of organic vegetables [29], or to pelletize the compost [30]. Some Italian farmers pelletize the compost since the dried pellets have a volume of only $60-90 \%$ of the raw compost and further concentrate manure nutrients [13]. 


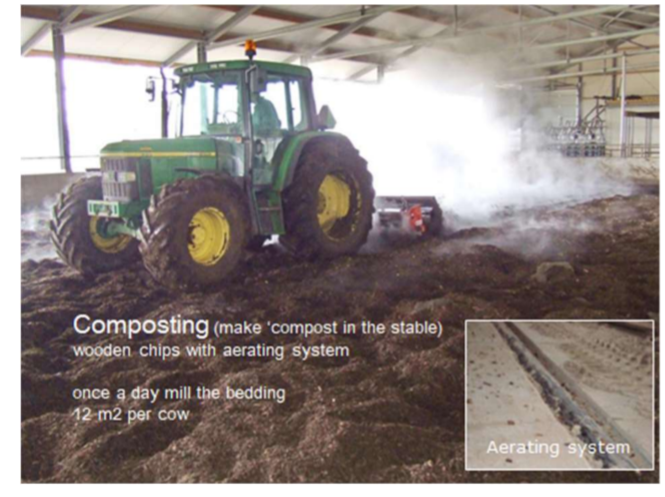

(a)

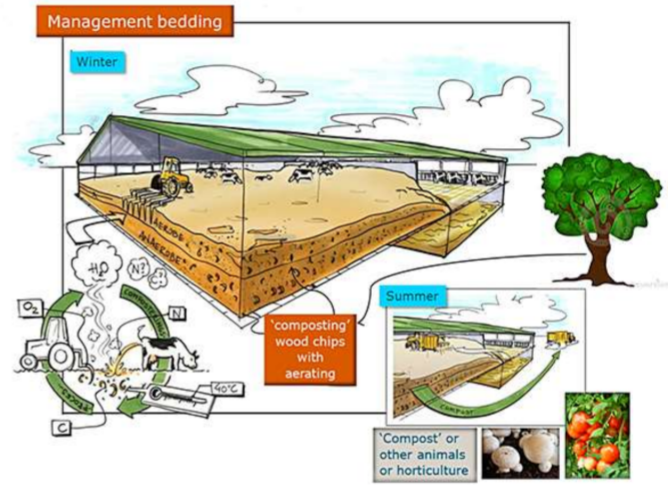

(b)

Figure 2. Illustration of the stimulation of the composting process by aerating the air (oxygen) into the pack (a), and the management and utilization of the bedded-pack (b).

Despite the relevant benefits of CBP, farmers' attitudes toward the multi-functional (alternative) use of a CBP have been minimally investigated. Hou [3] addressed farmers and agricultural advisors in several European countries (Denmark, Italy, The Netherlands and Spain) on the processing of manure for bioenergy production, stressing that this practice is considered important in Denmark and Italy but less important in Spain and the Netherlands. The major barriers to technology adoption were related to economic factors such as lack of investment capital, high processing cost and a long payback period, while there was relatively little concern regarding transport, noise burden, and health risks. Pampuro [13] analyzed the perceptions of farmers and agricultural advisors regarding the use of pelleted compost and found that they have a positive attitude toward the use of organic pellets and a lack of knowledge about the fertilizing aspects of the pellets, especially among farmers. The study by [31] on innovation in agriculture found that the majority of farmers have a cautiously positive attitude toward innovation, reflecting a pragmatic approach to business survival, regardless of farm and farmer characteristics.

Consumers' attitudes are key criteria for new food products or new agricultural practices and technologies [32]. Ultimately, public acceptance or rejection of agricultural practices will determine the commercial success of food products [33]. In the last two decades, consumers' concerns about the methods of food production have increased, especially in the developed world [34]. In general, procedures of food production and processing perceived as traditional, such as organic farming, are typically positively perceived by consumers; on the other hand, many consumers distrust certain production practices and technological innovations, such as genetically modified organisms [34]. Livestock production practices, such as growth hormones and confined animal housing, are becoming increasingly contentious [35]. Previous studies on consumers' attitudes toward livestock husbandry showed that consumers expressed the need to increase the level of welfare for farm animals, despite the fact that their level of knowledge about farming and animal welfare issues was relatively low [36-38]. Nowotny [39] recently showed that accepting new products or processes into the market is also a social process. New products and processes are in certain existing socioeconomic and technological regimes usually associated with a particular set of key technologies, mutual social practices, and general consumer behavior. It is evident that consumers have concerns regarding innovative and efficient modern agriculture practices; therefore, the question arises what attitudes they have toward alternative uses of CBP compost in cattle barns.

To our knowledge, no study to date addresses the perception of consumers and farmers in European countries regarding the alternative use of composted bedding material from cattle housing. Moreover, such food production practices in CBP barns are still at a limited scale and have an innovative character, thus these practices are scarcely described. Therefore, the study aims are threefold: first, provide an inventory of farmers' experiences 
with using composting bedding material for alternative uses; second, identify consumers' attitudes toward the use of compost in the production of alternative food products; third, assess consumers' perception and concern regarding the safety of the products produced in CBP. It should be noted that this study focuses on compost from cattle barns and not on other sources of compost such as household green waste.

\section{Materials and Methods}

2.1. Qualitative Research

\subsubsection{In-Depth Interviews with Cattle Farmers}

Impressions were gathered through six in-depth interviews with family farms that have been working and experimenting with alternative uses of composting bedded-pack material in recent years. In-depth interviews were conducted because they are useful in exploring new topics in detail, such as, in our case, the use of CBP [40]. Experiences from different farm settings in Slovenia, the Netherlands and Germany were described and discussed. These participants were selected because Dutch and German farmers are representatives of Western European farmers with larger farms and are more inclined to innovate, while Slovenian farmers are representatives of Central and Eastern European farmers with smaller farms and are more reluctant to innovate [41].

The main topics discussed were the attitude toward alternative uses of CBP, strengths and weaknesses of such multifunctional housing activities, and the motivation to pursue these alternative business set-ups. The interviews were conducted in 2019 and 2020 onsite and lasted about one hour. All interviews were transcribed into English for analysis. Common themes and issues were identified after detailed summaries were produced. This analysis also serves as background and illustration of the still rather unknown multifunctional compost and housing use for cattle.

\subsubsection{Consumer Focus Groups}

The compost bedded housing system and uses of compost from this system for products other than for milk production are relatively new approaches for the average consumer. Focus groups are often implemented to explore concepts that are unfamiliar to consumers and are used to help identify important viewpoints that can be further examined in quantitative research [40]. Therefore, focus groups were conducted to gain a better understanding of how consumers perceive these ideas and generate concepts to be tested in a larger quantitative survey. Further topics related to animal welfare in general and perceptions of cow husbandry systems were also discussed because the focus groups and quantitative survey were part of a larger project related to freewalk cow housing systems (www.freewalk.eu, accessed on 20 November 2020).

Six focus groups were conducted in October 2018 in Vienna, Austria ( $n=19)$, Munich, Germany $(n=20)$, and Ljubljana, Slovenia $(n=15)$. Locations were chosen to represent differences in willingness to pay (WTP) based on the Eurobarometer 442 survey results [42]: Slovenia represents a low WTP, Austria a medium WTP, and Germany a high WTP. An earlier Eurobarometer report [43] concluded that in Slovenia most consumers disagree with the claim that food is safer today than it was 10 years ago, whereas in Germany and Austria more people agreed with this statement.

Two sessions in each location took place for an average of $90 \mathrm{~min}$ with seven to ten participants. Participants were screened to be non-vegans and soft quotas were used for age, gender, and education levels. Sessions were overseen by a moderator who received training from an experienced qualitative researcher. The same discussion guide was used in all sessions and included questions regarding purchase decisions for animal products, animal welfare in general and for cows, cow housing systems (including the compost bedded system) and grazing, and the compost material from the compost bedded system. This paper focuses on the results from the compost discussion. Participants were asked to brainstorm ideas regarding the use of the compost prior to being shown pictures of examples of products made from the compost. They were then asked how much they 
(dis)liked the compost idea and any concerns they had about products from this system, including how safe they would feel eating a food product grown in the compost. All sessions were video- and audio-recorded and transcribed into English for the analysis. Common themes and topics were determined after producing detailed summaries.

\subsection{Quantitative Research}

\subsubsection{Farmer Quantitative Surveys}

A farmer-specific survey was conducted in 2019 using a questionnaire in six European countries (Austria, Germany, Italy, the Netherlands, Slovenia, Sweden) representing different parts of Europe, involving cattle farmers who are familiar with both the CBP housing system and the common cubicle (freestall) housing system. These farmers participated in the ERA-NET SusAn project FreeWalk, which made them experienced in this area of cattle housing with and without composting bedding material as a resting place for the cows. They were asked to fill in the questionnaire in the local language during group meetings or when visiting the farms. Soft guidance was given, meaning that the farmer could ask the researcher to explain a question. The surveyed farmers $(n=80)$ were spread over the six countries as follows: 46 from the Netherlands, 14 from Germany, 6 from Austria, 6 from Italy, 4 from Slovenia and 4 from Sweden. Half of the farmers managed a CBP barn (case farm) and the other half a cubicle barn (reference farm). These were dairy farms, except 1 CBP barn and 1 cubicle barn from suckler cow herds in both Germany and Slovenia. Each case farm was matched with a similar reference farm with respect to size of herd, overall management and landscape. The farms averaged from 40 cow herds in Austria to 120 cow herds in the Netherlands to 200 cow herds in Germany in 2017, with quite some variation in the latter country.

The farmers were asked to score their opinion using a 7-point rating scale ( 1 = "very negative", 7 = "very positive") about the CBP compared to a cubicle housing system for the following criteria: annual costs of compost bedding material versus cubicle material, smell in barn, composted bedding material versus slurry-manure as soil improver, composted bedding material versus slurry-manure as fertilizer, in addition to opportunities for creating better animal life certificates, marketing high-quality dairy products, and marketing high-quality manure products.

Differences in the ratings of opinions of the farmer groups representing the two housing systems were evaluated by using the Mann-Whitney significance test. Statistical difference was set at $0.1 \%, 1 \%$ and $5 \%$ probability levels.

\subsubsection{Consumer Quantitative Survey}

A consumer survey was used to gain further insights into the concepts discussed in the focus groups. The survey was conducted online through a market research firm in eight European countries (Austria, Germany, Italy, the Netherlands, Norway, Slovakia, Slovenia and Sweden) in spring 2019. Quotas were in place to be nationally representative for age and gender. Soft quotas were used for residence area, education, and income. There was a total number of 3693 participants: 415 from Austria, 633 from Germany, 592 from Italy, 423 from the Netherlands, 401 from Norway, 410 from Slovakia, 397 from Slovenia and 422 from Sweden. Participants were screened to be non-vegan, milk consumers, responsible for at least part of the household food shopping and not currently live on a farm with livestock. Table 1 shows an overview of socio-demographic variables for the total sample.

The questionnaire included questions regarding food purchasing behavior, animal welfare, housing system acceptance, and attitudes toward alternative use of compost from the CBP, which is the focus of this paper. In two parts of the questionnaire, pictures of the various barns were shown. After introducing the concept of compost through a brief description, participants were asked how worried they were about the safety of the food they eat in general on a 10-point scale ( $1=$ "not worried at all", $10=$ "very worried"). Consumers were then asked how safe they felt consuming food products that are grown using the compost also on a 10-point scale $(1=$ "not safe at all", $10=$ "fully safe"). Those that 
answered 6 or less were asked a follow-up open-ended question to state what concerns they had about consuming food products that are grown using the compost. Lastly, participants were asked to select statements about what they thought regarding alternative uses of the compost.

Table 1. Socio-demographic profile of the sample $(n=3693)$.

\begin{tabular}{|c|c|c|c|c|c|}
\hline & & $\%$ & & & $\%$ \\
\hline \multirow{2}{*}{ Gender } & Male & 50.56 & \multirow{3}{*}{ Area } & Rural & 27.92 \\
\hline & Female & 49.23 & & Suburban & 23.77 \\
\hline \multirow{6}{*}{ Age } & $18-24$ & 11.32 & & Urban & 48.31 \\
\hline & $25-34$ & 17.76 & \multirow{5}{*}{ Education } & No degree & 3.25 \\
\hline & $35-44$ & 18.60 & & Trade/Vocational & 31.98 \\
\hline & $45-54$ & 20.31 & & High School & 35.85 \\
\hline & $55-64$ & 16.33 & & University & 27.08 \\
\hline & $65+$ & 15.68 & & Ph.D. & 1.84 \\
\hline
\end{tabular}

ANOVA followed by the post-hoc Tukey's HSD test $(p<0.05)$ was used to compare mean scores of food worry and safety consuming foods grown in the compost. Opinion statements regarding the use of the compost were evaluated by Chi-square z-tests using the Bonferroni's correction $(p<0.05)$.

\section{Results}

\subsection{In-Depth Interviews with Cattle Farmers}

The six participants reported on the introduction of the multi-functional use of a CBP barn during the months when the cows are out to pasture. During this period, the equipment and/or composting bedded-pack are used for various production practices, such as the use of composting bedding material for fattening pigs and the cultivation of vegetables and fruits. The bedding material plus manure is reused to complete the nutrient or energy cycle. All interviewed farmers described the functioning of the composting bedded-pack. Moreover, the management of the bedded-pack was monitored as part of the FreeWalk project.

The first participant from Slovenia described his experience with the multi-functional use of the CBP on the Experimental farm Logatec, where two badges of about 20 to 25 pigs had been raised and fattened during the period from June until November in both 2018 and 2019 on the composting bedding materials. The suckler cows with calves were grazing during these months. The barn was somewhat adapted to the housing of pigs by installing a simple fence, preventing the pigs from stepping out: "With using the suckler-cows barn during grazing season for raising and fattening of pigs in the compost bedded-pack barn, we use the otherwise unused barn for fattening of pigs and to provide additional income on the farm [see Figure 3]. We had very positive experiences raising pigs on the compost. No single health incidence was encountered during both years. Pigs had a very good daily gain with a lot of space ( 4 to $5 \mathrm{~m}^{2} / \mathrm{pig}$ )". The participant had a positive attitude toward the reuse of CBP for fattening of pigs. His main motivation was to create added value on the basis of "happy pigs" and provide additional income. The second product from the multi-functional use of the barn was quality compost to use for fertilization of permanent grassland soils and better quality of grassland crops. The main weakness was labor costs resulting from the daily cultivation of bedding material and getting suitable material (by-products—sawdust, miscanthus, straw) for the resting area. Pigs also play with water and the area around the drinkers was often too wet. Regarding the future development of this system, he stated that "such a sustainable farming system can be very suitable for organic and smaller family farmers with suckler cows or small ruminants which stay on pasture from beginning till the end of the growth grass season". 


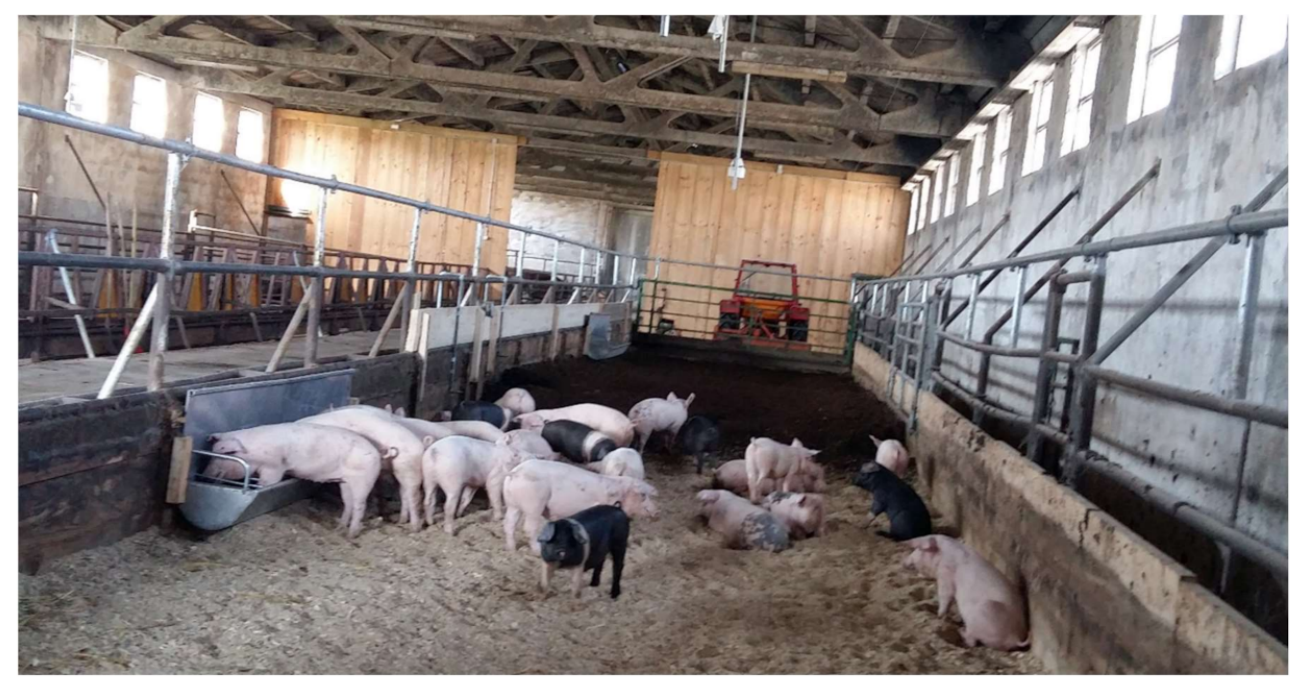

Figure 3. Utilizing composting bedded-pack barn for fattening of pigs during grazing season (Experimental farm Logatec, Slovenia).

The second participant, from the farm Veld \& Beek in the Netherlands, an organic run farm with about 40 cows on sandy soils, reported that during the grazing period, the CBP barn is utilized for growing horticultural products, like tomatoes and cucumbers (see Figure 4). The building has a greenhouse type roof to allow sunlight to enter. He explained that they first need to prepare the planting area. For maximum growth, a top layer of about $10 \mathrm{~cm}$ of sandy soil is spread over the composting bedded-pack. The plant roots will develop in the top layer and reach the bedding material with manure as the fertile second layer. After the plant production season, the lying bed for the cows is restored. He had a positive attitude towards the system, which is very much appreciated by the clients, among others, because it creates a very pleasant environment with a good story: the barn is utilized all year-round and the bedding material and manure are used from animal to consumable plant. As a result, the farm can now sell a mixture of agricultural products. The production and marketing cycles are all within one farm and all processes are visible for the visiting clients. However, this system has also a few serious disadvantages. Firstly, the addition of sand to the bedding and later on the removal of this layer is a tedious job and needs to be repeated each year. Secondly, the horticultural branch requires quite some extra, temporary labor. These labor aspects were seen as troublesome by the interviewed participant and threatened the future viability of the system.

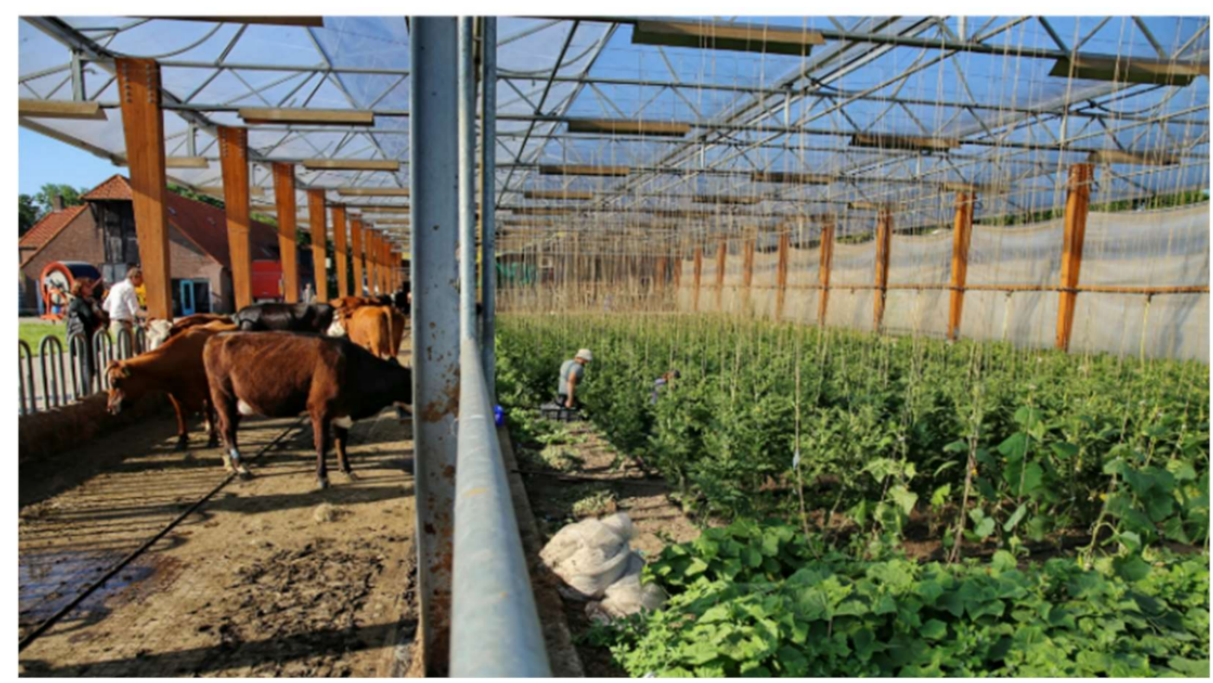

Figure 4. Utilizing composting bedded-pack barn for growing horticultural products (farm Veld \& Beek, Doorwerth, The Netherlands). 
The third participant was farmer from Koonstra in the Netherlands, who completed in May 2015 the construction of a CBP barn that combines different activities utilizing the composting bedded-pack material. His barn was constructed including pipes circulating water below the bedded-pack barn for picking up the heath that develops from the beddedpack. The heath (i.e., energy is transported and used for warming up the visitors' room) and the water are partly delivered in the drinkers for the cattle in the barn, especially during winter time. Moreover, the farm Koonstra sells their own homemade cheese, called "freewalk compost cheese" (vrijloopkaas; see Figure 5). During Christmas time they sell Christmas trees and use the leftovers as bedding material in the barn. Farm Koonstra entertains a lot of visitors telling their story. The farmer stated that a leading principle is to "put the carbon from the wood chips in the soil instead of in the air". Additionally, he stated that "compost bedded-pack barns are a good story for marketing, based on happy cows and fertile soils". This farm is driven by innovation, communication and creating a circular economy.

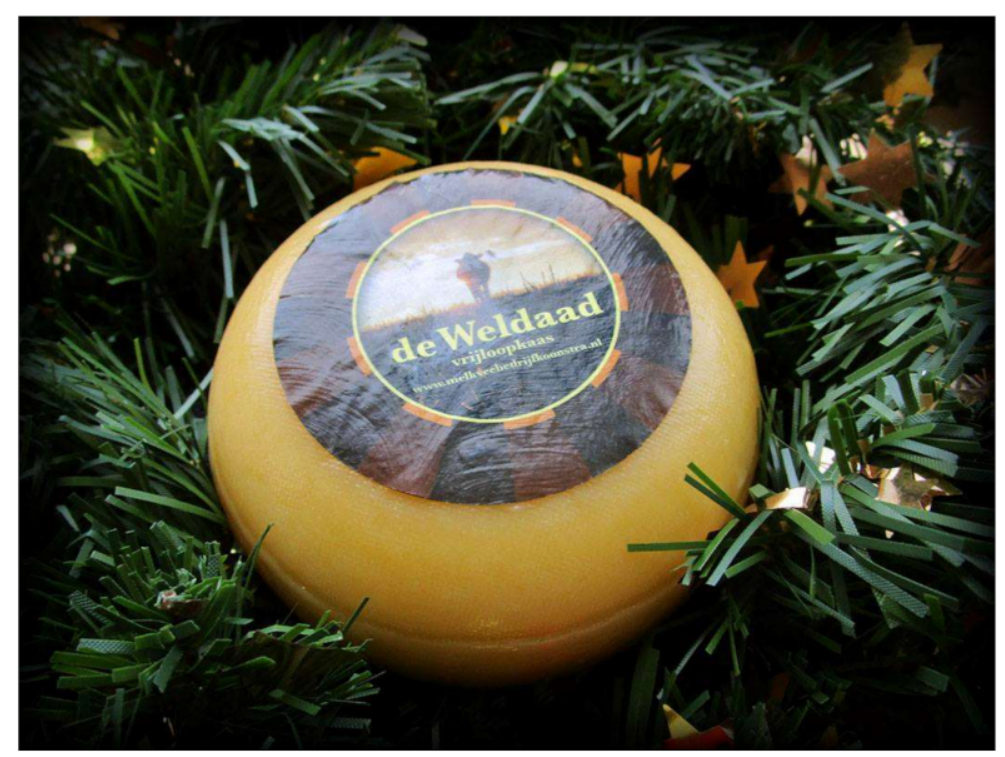

Figure 5. Freewalk cheese from cows on composting bedding material (farm Koonstra, Vinkenbuurt, The Netherlands).

The fourth and fifth interviews represented a group of farmers dealing with the marketing of the composted bedded-pack. Dairy farmer Marc Havermans in the Netherlands processed pellets from his bedding material for a one-year period (see Figure 6). The processing of pellets did work, but after evaluation he considered it as too laborious to organize the whole chain from farm to consumer. On the other hand, a big CBP dairy farm in Germany has produced compost pellets for 10 years and succeeded in building a market channel for this product. That farmer saw it as a very competitive business. In fact, the selling of bedding material mixed with manure processed to pellets or, more often, as natural organic material in bags is presently believed to be the most widespread alternative use of CBP material.

The sixth interview focused on reusing within the farm and increasing the economic efficiency of using the bedding material instead of focusing on marketable products. German farmer Gunther Boss extended his cubicle housing with a compost bedded-pack barn for 36 fresh lactating cows to increase the cows' comfort while resting. Around 75\% of the compost is reused as bedding material in the 130 cubicle stalls and the remaining $25 \%$ is used as fertilizer in the field cultivation. He stated that a reduction in total bedding material costs of $80 \%$ has been achieved. Next, the bedding material from the cubicles is used as an input for the biogas plant, also on this farm, producing energy. Due to this, a circular economy was realized on this farm. 


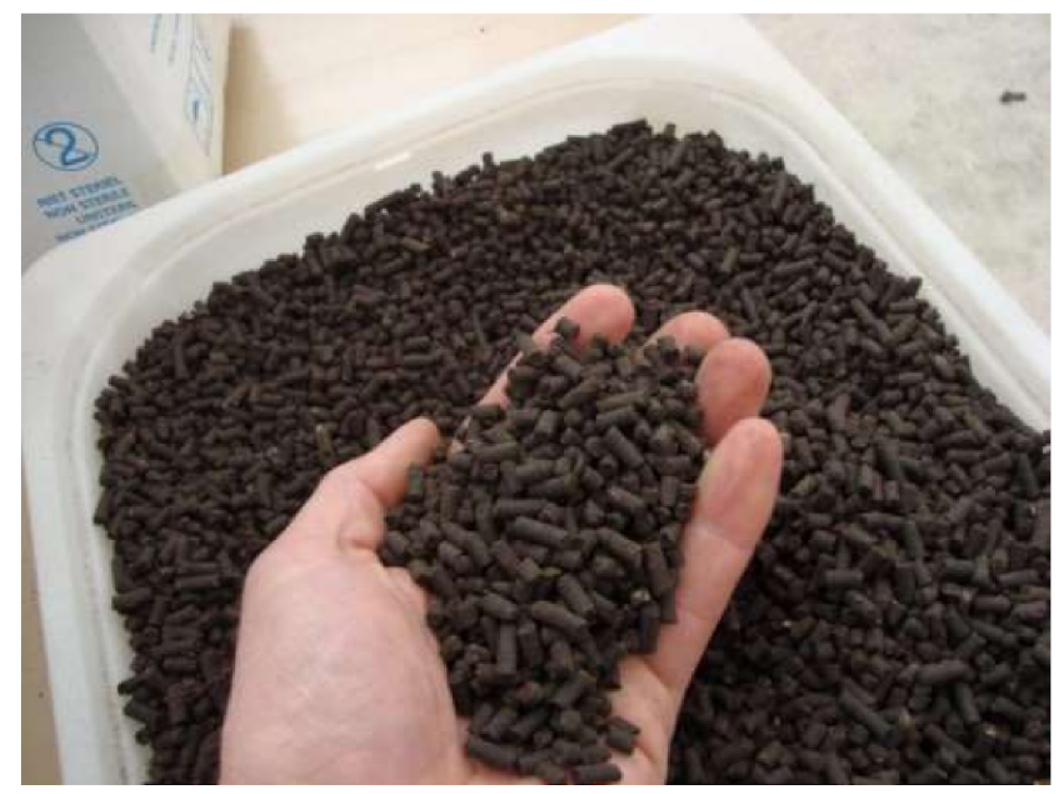

Figure 6. Pellets produced from composting bedded-pack material.

\subsection{Consumer Focus Groups}

Initially, participants of the focus groups were informed about the CBP system and that the compost could be used for other purposes. They were then asked to imagine what products they would develop or other usage options for this compost. There was considerable overlap in responses among the locations, and in all countries, participants thought of using the compost for fertilizer, soil, and energy. A few participants emphasized the possibility of alternative use of compost as residential heating energy: "Yes, it could be used to heat houses and other buildings" (Milena, Slovenia). One Slovenian and Austrian also mentioned it could be processed into fuel for transport. As the trend in Slovenia is so-called "eco-construction", one interviewee said it could be used as an organic building material. In line with popular discussions on alternative protein consumption, an Austrian participant suggested that the compost be used for breeding earthworms since these are useful as a "protein replacement" (Barbara, Austria).

After the initial brainstorming, example pictures of particular uses for the compost were shown and discussed (e.g., mushroom farming, raising of pigs, pellets). The idea of raising pigs was received positively overall. For example, Marjana (Slovenia) stated, "This would be most useful for farmers. I also think the pigs on this compost would be very happy." Mushroom farming also was seen by some as a particularly nice idea in Austria and Germany. A German participant also mentioned "It's good, that you can use the compost again, it seems like it really works with the mushrooms produce, the pigs look happy and also the cows seem to be relaxed" (Annika, Germany).

Overall, there was a positive perception of using the compost for other purposes; however, certain food safety and practical concerns were raised in all countries. In Slovenia, the only food safety concern mentioned was eating salad greens due to proximity to the animal waste. However, if there was limited cow contact with the vegetables and proper barn ventilation this was no longer a concern. One additional participant also mentioned concern over antibiotics and feed quality effects on the compost. Participants in Austria and Germany also expressed concern about how the feed and antibiotic use could affect the quality of the compost. Several Austrian participants commented that they would not want to use compost as fertilizer due to these concerns. There was also skepticism about using the compost for produce and eating products from this system. A German participant expressed concerns about how the cow's diet could affect the products: "It really depends to the food of the cattle. It is not safe to say, whether the compost is ok. It depends more to what poisonous substances the cow ate and what goes to the compost through the cow's 
excrements" (Lisa, Germany). Another participant mentioned concerns regarding lettuce or uncooked mushrooms in addition to the pigs getting too dirty. In Germany, most felt safe eating products from the compost system, a few were unsure, and about a quarter did not feel safe. In Austria, while some did appreciate the idea of reusing the compost and had fewer concerns, there seemed to be more hesitancy due to either lack of information or safety concerns. The effect on the taste of foods grown in the compost was also brought up slightly in Austria and Slovenia. For instance, Brane from Slovenia stated, "If one doesn't produce vegetables in such a system and doesn't taste it, one cannot say what is good or not. One needs to taste it and then one can say 'it's okay'". Lastly, many participants wanted more knowledge about the system to fully assess the pros and cons of using the compost for other uses.

In all countries, participants brought up the added benefit of extra income for farmers in addition to the sustainability aspects of this system. It was also mentioned in Germany about the possibility of it leading to higher animal welfare: "Maybe the farmer can get more income through this. And it is possible to offer more animal welfare because he earns more money" (Sonja, Germany). In Slovenia, there was further discussion over which would be more profitable for the farmer: pigs, vegetables, or pellets. Some felt having food through pigs and vegetables was more important than extra profit from pellets. On the other hand, an Austrian interviewee emphasized the use of extra energy as a potential negative factor for the use of CBP for pellets: "I mean, when it is pressed to pellets, it seems like a huge amount of energy is needed" (Sabine, Austria), which may make the system appear to be less sustainable. Furthermore, a few Slovenian interviewees expressed barriers to successful reuse of CBP. For example, Milena stated the compost from the CBP would be of higher quality and value compared to the cheaper, oversupplied vegetable/organic waste compost currently on the Slovenian market. Costs for the farmer and market price barriers were also mentioned for meat and vegetables grown on the compost. Furthermore, one-fifth of Slovenian participants thought the lack of proper agricultural marketing, such as through television shows, makes it difficult for consumers to distinguish quality products and this would create a willingness to pay higher prices for specialty foods.

\subsection{Survey Results}

\subsubsection{Farmers' Perceptions}

First, an inventory is presented of composting bedding materials on the 80 surveyed farms. By-products from wood were mostly used as bedding materials for cow housings. On the Netherlands' CBP farms, 50\% of farmers used wood shavings (chips) and almost $35 \%$ used straw, and 15\% a mixture of wood and straw, sometimes adding hay to it. In Germany, half of farmers used mixtures of grain by-products, spelt, sawdust and chopped rape straw. In Austria the farmers used sawdust plus spelt hulls, and in Italy and Slovenia sawdust, wood chips, straw and miscanthus.

The selected farmers from the Netherlands, Germany and the other four European countries expressed quite similar opinions toward aspects related to the bedding material and slurry (manure plus urine) quality from the CBP and cubicle housing system, respectively (Table 2 ).

The CBP was considered as a system that was more sustainable and offered more market opportunities than the common cubicle housing system by the farmers from all six countries. The composted bedding material was judged as a better soil improver. Farmers in the Netherlands also saw it as a better fertilizer than slurry, while these farmers experienced the smell in a bedded-pack barn housing to be less distinct than in a cubicle housing system. However, the cost of the bedding material needed for the CBP was considered by all farmers to be a highly significant negative aspect of this system. 


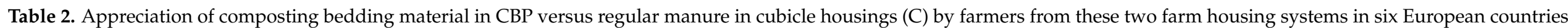
(scores from 1 = Very Negative to 7 = Very Positive) ${ }^{123}$.

\begin{tabular}{|c|c|c|c|c|c|c|c|c|c|c|c|c|c|c|c|c|}
\hline & \multicolumn{4}{|c|}{ Netherlands } & \multicolumn{4}{|c|}{ Germany } & \multicolumn{4}{|c|}{ Four Other Countries Summed } & \multicolumn{4}{|c|}{ All Six Countries Summed } \\
\hline & CBP & $\mathrm{C}$ & $\mathrm{CBP}-\mathrm{C}$ & $\begin{array}{c}\text { Mann- } \\
\text { Whitney } \\
\text { Test }\end{array}$ & CBP & $\mathrm{C}$ & $\underset{\mathrm{C}}{\mathrm{CBP}-}$ & $\begin{array}{c}\text { Mann- } \\
\text { Whitney } \\
\text { Test }\end{array}$ & СВP & $\mathrm{C}$ & $\underset{\mathrm{C}}{\mathrm{CBP}-}$ & $\begin{array}{c}\text { Mann- } \\
\text { Whitney } \\
\text { Test }\end{array}$ & СВР & $\mathrm{C}$ & $\underset{\mathrm{C}}{\mathrm{CBP}-}$ & $\begin{array}{c}\text { Mann- } \\
\text { Whitney } \\
\text { Test }\end{array}$ \\
\hline \multicolumn{17}{|c|}{ Cost aspect } \\
\hline Cost of bedding material & 3.92 & 5.47 & -1.55 & 0.00 ** & 3.43 & 5.71 & -2.28 & $0.02 *$ & 2.80 & 5.50 & -2.70 & $0.000 * * *$ & 3.58 & 5.53 & -1.95 & $0.000 * * *$ \\
\hline \multicolumn{17}{|c|}{ Sustainability aspects } \\
\hline $\begin{array}{l}\text { Bedding material/slurry as soil } \\
\text { improver }\end{array}$ & 6.35 & 3.44 & 2.90 & $0.00 * *$ & 6.00 & 2.86 & 3.14 & $0.00 * *$ & 5.60 & 4.80 & 0.80 & 0.26 & 6.15 & 3.61 & 2.54 & $0.000^{* * *}$ \\
\hline $\begin{array}{l}\text { Bedding material/slurry as } \\
\text { fertilizer }\end{array}$ & 5.92 & 3.44 & 2.48 & $0.00 * *$ & 5.57 & 4.86 & 0.71 & 0.29 & 5.67 & 5.11 & 0.56 & 0.26 & 5.82 & 4.06 & 1.76 & $0.000^{* * *}$ \\
\hline Smell & 6.23 & 4.40 & 1.83 & $0.00 * *$ & 5.14 & 4.14 & 1.00 & 0.17 & 5.89 & 5.11 & 0.78 & 0.34 & 5.98 & 4.53 & 1.45 & $0.000 * * *$ \\
\hline \multicolumn{17}{|c|}{ Marketing aspects } \\
\hline Better animal life certificate & 6.04 & 3.17 & 2.88 & $0.00 * *$ & 6.00 & 3.28 & 2.72 & $0.00 * *$ & 6.13 & 4.50 & 1.63 & 0.04 * & 6.05 & 3.52 & 2.54 & $0.000^{* * *}$ \\
\hline High-quality dairy products & 5.88 & 3.79 & 2.09 & $0.00 * *$ & 5.43 & 4.14 & 1.29 & $0.04 *$ & 5.38 & 4.63 & 0.75 & 0.28 & 5.69 & 4.06 & 1.63 & $0.000 * * *$ \\
\hline High-quality manure products & 5.81 & 3.16 & 2.65 & $0.00 * *$ & 5.43 & 2.86 & 2.57 & $0.00 * *$ & 5.44 & 4.13 & 1.31 & $0.03^{*}$ & 5.67 & 3.32 & 2.34 & $0.000^{* * *}$ \\
\hline
\end{tabular}

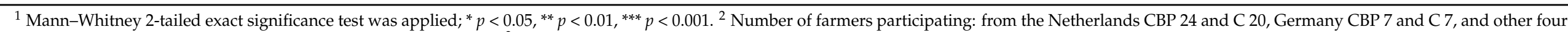
countries (Austria, Italy, Slovenia and Sweden) CBP 10 and C 10. ${ }^{3}$ Question about »better life certificate« was not answered by the Swedish farmers, because this concept is not known in that country. 


\subsubsection{Consumers' Perceptions}

Overall, consumers worried about the safety of their food (Table 3a), but generally would feel safe consuming food products that were grown using the compost from the CBP barns (Table $3 b$ ). A closer look by country showed that Slovenia and Italy worried the most about food safety in general, while Austria, the Netherlands, Norway, and Sweden worried the least about food safety. Consumers from Norway, Slovenia and Sweden indicated they felt significantly more safe consuming food products from the CBP than those from the other countries; however, Sweden did not differ significantly from Slovakia and Austria. Males seemed to worry significantly less than females regarding food safety and felt significantly safer about food from the CBP. Consumers between 25 to 44 years old felt more worried about food safety than consumers of 65 and older. Furthermore, those between 18 and 24 years old indicated they felt significantly less safe about food grown in the barn compost than all other age groups. Those in urban areas also worried significantly more about the safety of their food than those in suburban areas and felt significantly less safe about food from the compost than those in rural areas. There were few differences by education level, but those with a university degree felt more worried about food safety than those with a trade or vocational degree, in addition to feeling safer about food from the CBP than those without a degree.

Table 3. Mean scores and standard deviations for worry about (a) the safety of food consumed in general ( 1 = "Not Worried at All" to $10=$ "Very Worried") and (b) safety of consuming food products using the compost from the compost bedded housing system ( 1 = "Not Safe at All", 10 = "Fully Safe"); by country, gender, age, area, education, and in total. ${ }^{1,2}$.

\begin{tabular}{|c|c|c|c|c|}
\hline \multirow[b]{2}{*}{ Variable } & \multicolumn{2}{|c|}{ (a) Food Safety Worry in General } & \multicolumn{2}{|c|}{ (b) Compost Food Products Safety } \\
\hline & Mean & Std. Dev & Mean & Std. Dev. \\
\hline \multicolumn{5}{|l|}{ Country } \\
\hline Austria & $6.01^{\mathrm{cd}}$ & 2.20 & $6.98^{b c}$ & 1.85 \\
\hline Germany & $6.15^{c}$ & 2.18 & $6.87^{\mathrm{c}}$ & 1.86 \\
\hline Italy & $7.62^{\mathrm{a}}$ & 1.79 & $6.85^{c}$ & 1.90 \\
\hline Netherlands & $5.65^{\mathrm{d}}$ & 2.15 & $6.79^{\mathrm{c}}$ & 1.66 \\
\hline Norway & $5.65^{\mathrm{d}}$ & 2.67 & $7.40^{\mathrm{a}}$ & 1.97 \\
\hline Slovakia & $6.94^{\mathrm{b}}$ & 2.22 & $6.93 \mathrm{bc}$ & 2.00 \\
\hline Slovenia & $7.88^{a}$ & 2.10 & $7.63^{\mathrm{a}}$ & 2.24 \\
\hline Sweden & $5.77^{\mathrm{cd}}$ & 2.43 & $7.23 \mathrm{ab}$ & 2.09 \\
\hline \multicolumn{5}{|l|}{ Gender } \\
\hline Male & $6.31^{\mathrm{b}}$ & 2.43 & $7.17^{\mathrm{a}}$ & 2.01 \\
\hline Female & $6.67^{\mathrm{a}}$ & 2.28 & $6.96^{\mathrm{b}}$ & 1.90 \\
\hline \multicolumn{5}{|l|}{ Age } \\
\hline $18-24$ & $6.39 \mathrm{abc}$ & 2.13 & $6.58^{b}$ & 2.01 \\
\hline $25-34$ & $6.73^{a}$ & 2.25 & $7.12^{\mathrm{a}}$ & 1.91 \\
\hline $35-44$ & $6.69^{\mathrm{ab}}$ & 2.25 & $7.19^{\mathrm{a}}$ & 1.93 \\
\hline $45-54$ & $6.37^{b c}$ & 2.39 & $7.01^{\mathrm{a}}$ & 1.97 \\
\hline $55-64$ & $6.42^{\mathrm{abc}}$ & 2.29 & $6.99^{a}$ & 1.90 \\
\hline $65+$ & $6.27^{c}$ & 2.73 & $7.24^{\mathrm{a}}$ & 2.00 \\
\hline \multicolumn{5}{|l|}{ Area } \\
\hline Rural & $6.50^{\mathrm{ab}}$ & 2.49 & $7.22^{\mathrm{a}}$ & 2.05 \\
\hline Suburban & $6.30^{\mathrm{b}}$ & 2.31 & $7.01^{\mathrm{ab}}$ & 1.87 \\
\hline Urban & $6.58^{\mathrm{a}}$ & 2.31 & $6.99^{b}$ & 1.95 \\
\hline \multicolumn{5}{|l|}{ Education } \\
\hline No degree & $6.37^{\mathrm{ab}}$ & 2.64 & $6.58^{\mathrm{b}}$ & 2.29 \\
\hline High School & $6.54^{\mathrm{ab}}$ & 2.33 & $7.01^{\mathrm{ab}}$ & 2.01 \\
\hline Trade/Vocational & $6.33^{b}$ & 2.39 & $7.04^{a b}$ & 1.89 \\
\hline University & $6.61^{\mathrm{a}}$ & 2.33 & $7.23^{a}$ & 1.92 \\
\hline Ph.D. & $6.65^{\mathrm{ab}}$ & 2.38 & $6.85^{\mathrm{ab}}$ & 2.19 \\
\hline Total & 6.49 & 2.36 & 7.06 & 1.96 \\
\hline
\end{tabular}

${ }^{1}$ Different letter $(a, b, c, d)$ within each mean column section indicates significant differences between variable options as evaluated by Tukey's HSD $(p<0.05) .{ }^{2}$ Number of consumers who participated in the survey from Austria was 415, Germany 633, Italy 592, the Netherlands 423, Norway 401, Slovakia 410, Slovenia 397, and Sweden 422 .

Around $36 \%$ of total consumers rated a 6 or lower when asked about how they felt consuming food products that were grown in the compost. The follow-up openended question revealed that many did not know why they felt concerned about eating 
food products from this compost system or were cautious and needed more information. However, some common responses were related to concerns about antibiotic seepage, hygiene, and bacteria.

Table 4 displays results regarding what consumers thought about using the CBP compost for different categories of products and in general by country and in total. Despite feeling safe overall about eating products from the compost, around half of all consumers indicated the compost should be used for non-edible products rather than edible products. Using the composting bed to raise other animals (e.g., pigs, chickens) was considered an option by around a quarter of consumers. Furthermore, a little more than a third of consumers thought reusing the compost created a more sustainable system, and 3 in 10 consumers thought it was a good way for farmers to receive extra income. Only 5\% thought the compost should not be used for any other purpose, and around $17 \%$ indicated they needed more information before deciding about what they thought about the compost.

Table 4. Consumer opinions on alternative uses of compost from the CBP by country and in total (in percentages of agreement per country).

\begin{tabular}{|c|c|c|c|c|c|c|c|c|c|}
\hline & AT & DE & IT & NL & NO & SK & SI & SE & Total \\
\hline $\begin{array}{c}\text { Use for } \\
\text { non-consumable products }\end{array}$ & $56.9^{a b c}$ & $51.2^{\mathrm{bcd}}$ & $52.5^{\mathrm{bcd}}$ & $43.0^{\mathrm{d}}$ & $60.6^{a b}$ & $55.9^{a b c}$ & $65.0^{\mathrm{a}}$ & $47.2^{d c}$ & 53.7 \\
\hline Raising animals & $32.5^{\mathrm{a}}$ & $25.4^{\text {abcd }}$ & $27.4^{\text {ad }}$ & $20.6^{\mathrm{cd}}$ & $33.4^{\mathrm{a}}$ & 23.9 abcd & $17.1^{\mathrm{bc}}$ & $33.7^{\mathrm{a}}$ & 26.7 \\
\hline $\begin{array}{l}\text { Growing produce that is } \\
\text { normally cooked }\end{array}$ & $42.4^{\mathrm{a}}$ & $35.6^{\mathrm{a}}$ & $36.3^{\mathrm{a}}$ & $35.7^{\mathrm{a}}$ & $44.6^{\mathrm{a}}$ & $37.3^{\mathrm{a}}$ & $35.3^{a}$ & $43.6^{\mathrm{a}}$ & 38.5 \\
\hline $\begin{array}{l}\text { Growing produce that is } \\
\text { normally uncooked }\end{array}$ & $30.1^{a b}$ & $22.6^{\mathrm{bc}}$ & $21.3^{c}$ & $18.2^{\mathrm{C}}$ & $25.9 \mathrm{abc}$ & $25.4^{\mathrm{abc}}$ & $25.2^{\mathrm{abc}}$ & $32.2^{\mathrm{a}}$ & 24.8 \\
\hline $\begin{array}{c}\text { Good way for farmers to get } \\
\text { extra income }\end{array}$ & $34.0 \mathrm{abc}$ & $31.3^{\text {abcde }}$ & $27.0^{\text {cde }}$ & $25.3^{\text {ce }}$ & 31.4 abcde & $35.9 \mathrm{ab}$ & $23.7^{\text {de }}$ & $36.5^{\mathrm{a}}$ & 30.5 \\
\hline $\begin{array}{c}\text { Creates a more } \\
\text { sustainable system }\end{array}$ & $45.8^{\mathrm{a}}$ & $39.0^{\mathrm{ab}}$ & $37.2^{\mathrm{ab}}$ & $27.7^{\mathrm{c}}$ & $35.2^{a b c}$ & $32.4^{b c}$ & $25.7^{\mathrm{c}}$ & $44.1^{\mathrm{a}}$ & 36.2 \\
\hline Need more information & $18.8^{\mathrm{a}}$ & $19.4^{\mathrm{a}}$ & $14.9^{\mathrm{a}}$ & $20.1^{\mathrm{a}}$ & $16.2^{\mathrm{a}}$ & $14.4^{\mathrm{a}}$ & $16.6^{\mathrm{a}}$ & $18.3^{\mathrm{a}}$ & 17.4 \\
\hline Compost should not be reused & $4.1^{\mathrm{a}}$ & $7.1^{\mathrm{a}}$ & $5.1^{\mathrm{a}}$ & $7.1^{\mathrm{a}}$ & $4.7^{\mathrm{a}}$ & $4.4^{\mathrm{a}}$ & $3.5^{\mathrm{a}}$ & $3.6^{\mathrm{a}}$ & 5.1 \\
\hline
\end{tabular}

Note: Different letters between column sections indicate significant differences between countries as evaluated by Chi-square z-tests across columns using Bonferroni's correction $(p<0.05)$. Reading guide, example: "use for non-consumable product" in Austria (abc) is significantly higher than in NL $\left({ }^{\mathrm{d}}\right)$, differences in all other countries $\left({ }^{\mathrm{a}}, \mathrm{b}\right.$, or $\left.^{\mathrm{c}}\right)$ are not significant.

Only a few country differences emerged for some of the response options. There were no significant differences between countries for thinking the compost could be used for growing produce that was normally cooked, thinking the compost could not be used for any alternative purpose, and needing more information. However, more Swedish consumers thought uncooked produce could be safely grown in the compost than those in Germany, Italy, and the Netherlands. Austrians also scored this option significantly higher than those in Italy and the Netherlands. Moreover, those in Austria, Sweden, and Norway thought other animals could be raised on the compost significantly more frequently than those in the Netherlands and Slovenia.

\section{Discussion}

This study focused on composting bedding material (CBP) from cattle barns. The term "composting" is used because the process of composting occurs year-round in the barn. Feces and urine from cows are dropped continuously on the bedding material, and oxygen is mechanically added to stimulate the composting process. The composting bedding material is annually removed from the barn. However, the temperature of the bedding material stays regularly below the optimum level of 40-50 degrees Celsius, especially in fall and winter, limiting the composting process [44]. Therefore, the resulting material has also been characterized as semi-compost, probably better expressing the composition of this product.

Alternative uses of this bedding material other than as a lying place for cattle were studied. The combination of qualitative and quantitative approaches has proved to be 
useful to provide a deeper insight into the perception of CBP use options by producers and consumers. A combination of methods was necessary, as no study has yet examined the perceptions of both consumers and farmers in European countries regarding the use of composted bedding material from cattle for other animals or as a soil improver and fertilizer for food crops.

The surveyed farmers in the various countries found the CBP system with composting materials to be more sustainable with respect to soil improvement and marketing opportunities than the cubicle housing system. However, the value of the compost material as fertilizer was more emphasized by the farmers from the Netherlands than by the farmers from the other countries as well as the positive aspect of reduced odor. The opinions from the other countries about the fertilizing ability of composting material was to some extent in line with expert opinions [44]. However, the cost of the bedding material required for the CBP was seen as a highly significant negative aspect for this system, which must be compensated for in the context of a multi-functional use of such a system, generating additional income, which was a crucial farmers' motivation for reusing the CBP, as was shown in the in-depth interviews. Farmers also pointed out that the multi-functional use of CBP in the case of the cultivation of horticultural products on the compost bedding during the summer showed additional weaknesses, for instance, in the sense of a lot of extra work in adding sand soil to the bedding and later in removing this layer of sand, and the horticultural work itself.

Results of the consumer survey showed that only few consumers (5\%) believed that compost should not be reused for any purpose. A larger proportion of respondents $(17 \%)$ stated that they had too little information to consider alternative use options of compost, which means that a communicative activity is needed to better inform consumers. About half of all consumers indicated that compost should be used for non-edible products rather than for edible products. Due to the concerns expressed in the focus groups, compost was likely to be used less for food products that were typically uncooked (e.g., salad) than for food products that were normally cooked (e.g., eggplant). This was also confirmed by the result that more than one-third of the surveyed consumers had reservations about consuming food grown in compost. The focus group discussion revealed concerns about antibiotic infiltration and bacteria in the compost. Therefore, these potential problems should be tested and addressed to the consumer before edible products grown in this compost are marketed. In addition, consumers thought the compost could be used for raising other animals (e.g., pigs, chickens). The focus group participants agreed that using the compost for more purposes does create a more sustainable system. It improves the quality of organic manure and, therefore, has a positive effect on soil quality and structure and humus content in the soil. It is a good way for farmers to generate additional income.

Swedish consumers believed that uncooked products could be grown in compost more than consumers in Germany, Italy and the Netherlands indicated. This could be explained by the Swedish tradition of raw food, which prefers uncooked food products more than in other Western and Southern European countries [45]. Similarly, the Netherlands selected using the compost for non-consumable products significantly less than all countries, except Germany, Italy and Sweden. In addition, consumers in Austria, Sweden and Norway were of the opinion that other animals could be raised on the compost significantly more than in the Netherlands and Slovenia. This was in line with the conclusion of [39] that the acceptance of new products on the market is also a social process and that mutual social practices and general consumer behavior should be taken into account when introducing new products and practices. This was also confirmed by the results of the focus groups.

Consumers from Norway, Sweden, and Slovenia and those in rural areas claimed to feel safer than those in urban areas about eating food from the compost. Of particular interest was the perception of Slovenian consumers, who were most concerned about food safety in general, but who had a very positive attitude toward CBP and they most felt safe consuming food products grown in CBP. This can be explained by the fact that Slovenian consumers have little trust in social institutions such as politics, state, health, 
banks, judiciary and media [46], especially in the agricultural sector [47,48]. Men tended to be less concerned about new food products than women, and also those who lived in rural areas were less concerned than those from urban areas, partly because they had a better insight into the production process [49]. In addition, those between 18 and 24 years of age and with a university degree stated that they felt significantly less safe than all other age groups when eating food grown in compost. This was in line with the findings of [50,51] that the majority of well-educated and younger generations are skeptical about new food products and do not blindly believe in unknown claims of new products and verify them using the latest technology.

Opinions of participants in the focus groups on alternative uses of compost for fertilizer, soil and energy were in line with consumer trends in the individual countries. According to social trends, the Slovenian participants highlighted, for example, the use of compost as an organic building material, the importance of taste of products grown from compost, and the criticism that Slovenian television does not promote the quality of local food to increase the willingness of Slovenian consumers to pay higher prices for quality products. The Austrian participants suggested breeding earthworms, insect larvae, algae, or other living organisms, since these were useful as "protein substitutes", and the issue of needing additional energy as potentially negative for the reuse of CBP. The German participants expressed some concerns about how the cow's diet might affect products grown from compost, and also, how higher animal welfare might result in additional profit from the multi-functional use of CBP. Therefore, regional specificities should be taken into account when marketing the products of CBP.

Compost from CBP contains a lot of carbon that can be used to generate different types of biofuels, such as biogas, bio-oil and syngas. One interviewed farmer, as described in Section 3.1, also applied the biogas technique on his farm. Fiber from CBP could be reused for production of several special consumer products like peat substitute, seed starter pots, fertilizer garden sculptures, paper, and building materials (cited from [45]). The marketing of the composting materials as pellets was described for two farm cases. However, the production and sale of pellets was most common in poultry husbandry. Manure from poultry housings has as an advantage that the moisture content $(60-70 \%)$ is about the same or even higher than the composted bedding-manure material from CBP barns [44]. In the poultry sector (broilers) in Germany, bedding materials like corn spindle granules, wood shavings and spelt husks are used for exploration and manipulation by the animals. At the end of the 28-40-day fattening period this results in a very high-quality compost, that can be marketed after its use, if it is not being utilized on the farm itself. At a stocking density of $18-20$ animals $/ \mathrm{m}^{2}, 1 \mathrm{~kg}$ of bedding material $/ \mathrm{m}^{2}$ is converted to $0.8 \mathrm{~kg}$ of litter $/ \mathrm{kg}$ live weight at the end. Not only is the water-binding capacity of the material relevant, but more important is a good aeration system to bring the moisture of the bedding to the outside. The advantage of chickens is that they scratch, which means that they cultivate the material themselves. When this does not occur, as in the case of plate formation due to the feces being too wet from diarrhea, then mechanical help must be given. This is what generally occurs with compost bedded-packs of cattle housing. The same applies to poultry that do not scratch, such as turkeys. There is no composting process if the material is not mechanically cultivated.

The main limitation of the study is that the qualitative part of the consumer study was only conducted in three countries. Perhaps the inclusion of more countries could better justify the overlap in consumer and farmer perceptions regarding alternative CBP use or regional specificity. Moreover, the opinions of the farmers were based on real live experience with the two housing systems and the use and management of composting bedding material, while the consumers, especially from the large survey, needed some imagination to comprehend and picture a bedded-pack barn in their mind. The request for more information to base opinions on, as raised in the focus groups, is in line with this note. 


\section{Conclusions}

Alternative uses of composting bedding material from CBP barns other than as a lying bed for cattle were studied. The combination of qualitative and quantitative approaches proved useful in providing a deeper insight into the perceptions of CBP use options by both producers and consumers.

The surveyed farmers in the various countries found the CBP system to be more sustainable than the cubicle housing with slurry storage with respect to soil improvement and marketing opportunities. However, the cost of the bedding was seen as a highly negative aspect. Alternative use of the composted material in practice is still limited.

Growing of edible and non-edible produce on the composting bedding material in the summer months, while the cattle are grazing, is one route to generating more income. In general, participants in the focus groups appreciated such practices, but raised a concern of possible bacteria contamination from the compost. About half of the consumers surveyed indicated that compost should be used for non-edible products rather than for edible products. Nevertheless, compared to food safety generally, the surveyed consumers felt that food products grown on compost from CBP barns were relatively safe to consume. Better communication can help to inform consumers. In this context it is important to prevent bacteria from the compost transferring to the crops. Such potential concerns should be studied and then discussed with consumers before edible products grown on this compost are marketed.

The search for alternative uses of composting bedding materials from cattle barns is promising. It fits perfectly with the policy of promoting a circular economy at the farm level and helps in improving soil carbon content. However, there are several challenges to implementation. In addition, consumer perceptions, which differ among countries, should be carefully considered on the route to a more sustainable cattle farming system.

Author Contributions: Conceptualization, J.R., M.W., A.K. and M.K.; methodology, J.R., M.W., A.K. and M.K.; software, A.K.; validation, J.R., M.W., P.G., P.E., K.E., M.K. and A.K.; formal analysis, M.W., K.E. and A.K.; investigation, M.W., A.K. and M.K.; resources, M.K. and A.K.; data curation, M.W., A.K., K.E. and M.K.; writing-original draft preparation, K.E. and A.K.; writing-review and editing, A.K., K.E., J.R., M.W., P.G., P.E. and M.K.; visualization, K.E., M.W. and M.K.; supervision, A.K. and J.R.; project administration, A.K. and M.K.; funding acquisition, A.K. and M.K. All authors have read and agreed to the published version of the manuscript.

Funding: This research was funded by the European Union's Horizon 2020 Research and Innovation Program under Grant Agreement No 696231, for research carried out within the ERA-NET SusAn project "FreeWalk".

Institutional Review Board Statement: The study was conducted according to the guidelines of the Declaration of Helsinki.

Informed Consent Statement: Informed consent was waived as recruitment of participants to the focus groups and quantitative consumer study was done via Market Research Companies that used panels of previously registered panelists.

Data Availability Statement: The data presented in this study are available on request from the authors.

Acknowledgments: We wish to thank our FreeWalk partners Ulf Emanuelson and Isabel Blanco Penedo (Swedish University of Agricultural Sciences), Sven Koenig and Kerstin Brueggemann (Justus Liebig University Giessen, Germany), Jantine van Middelkoop (Wageningen Livestock Research, the Netherlands), Matteo Barbari and Lorenzo Leso (University of Firenze, Italy), Elfriede OffnerSchroeck and Andreas Zentner (Raumberg-Gumpenstein, Austria), Knut Hovstad (NIBIO, Norway), and Jan Tomka (National Agricultural and Food Centre, Slovakia) for assisting in translating, distributing and/or collecting questionnaires in their countries.

Conflicts of Interest: The authors declare no conflict of interest. The funders had no role in the design of the study; in the collection, analyses, or interpretation of data; in the writing of the manuscript, or in the decision to publish the results. 


\section{References}

1. Biasato, I.; D'Angelo, A.; Berone, I.; Odore, R.; Bellino, C. Compost bedded-pack barn as an alternative housing system for dairy cattle in Italy: Effects on animal health and welfare and milk product quality. Ital. J. Anim. Sci. 2019, 18, 1142-1153. [CrossRef]

2. FAO. Climate-Smart Agriculture (CSA)-Boosting Agricultural Productivity and Incomes While Adapting to Climate Change. 2019. Available online: https://www.fao.org/3/ca3942en/CA3942EN.pdf (accessed on 15 July 2020).

3. Hou, Y.; Velthof, G.L.; Case, S.D.C.; Oelofse, M.; Grignani, C.; Balsari, P.; Zavattaro, L.; Gioelli, F.; Bernal, M.P.; Fangueiro, D.; et al. Stakeholder perceptions of manure treatment technologies in Denmark, Italy, The Netherlands and Spain. J. Clean. Prod. 2018, 172, 1620-1630. [CrossRef]

4. Van Middelkoop, J. Phosphorus Use Efficiency on Dutch Dairy Farms. Ph.D. Thesis, Wageningen University, Wageningen, The Netherlands. (in final stage 30 April 2021).

5. European Environment Agency. European Union Emission Inventory Report 1990-2014 under the UNECE Convention on Long-Range Transboundary Air Pollution (LRTAP). 2016. Available online: https://op.europa.eu/it/publication-detail/-/ publication/0bd2cff8-e190-4a92-b749-1fa9a73b7225/language-en (accessed on 25 July 2020).

6. Fenlon, D.R.; Ogden, I.D.; Vinten, A.; Svoboda, I. The fate of Escherichia coli and E. coli O157 in cattle slurry after application to land. J. Appl. Microbiol. 2000, 88, 149S-156S. [CrossRef] [PubMed]

7. Jiang, X.P.; Morgan, J.; Doyle, M.P. Fate of Escherichia coli O157:H7 in Manure-Amended Soil. Appl. Environ. Microbiol. 2002, 68, 2605-2609. [CrossRef]

8. Jiang, X.P.; Islam, M.; Morgan, J.; Doyle, M.P. Fate of Listeria Monocytogenes in Bovine Manure-Amended Soil. J. Food Prot. 2004, 67, 1676-1681. [CrossRef]

9. Kudva, I.T.; Blanch, K.; Hovde, C.J. Analysis of Escherichia coli O157:H7 survival in ovine or bovine manure and manure slurry. Appl. Environ. Microbiol. 1998, 64, 3166-3174. [CrossRef]

10. Islam, M.; Doyle, M.P.; Phatak, S.C.; Millner, P.; Jiang, X.P. Survival of Escherichia coli O157:H7 in soil and on carrots and onions grown in fields treated with contaminated manure composts or irrigation water. Food Microbiol. 2005, 22, 63-70. [CrossRef]

11. Islam, M.; Morgan, J.; Doyle, M.P.; Jiang, X.P. Fate of Escherichia coli O157:H7 in manure compost-amended soil and on carrots and onions grown in an environmentally controlled growth chamber. J. Food. Prot. 2004, 67, 574-578. [CrossRef]

12. Bernal, M.P.; Alburquerque, J.A.; Moral, R. Composting of animal manures and chemical criteria for compost maturity assessment. A review. Bioresour. Technol. 2009, 100, 5444-5453. [CrossRef]

13. Pampuro, N.; Caffaro, F.; Cavalo, E. Reuse of animal manure: A case study on stakeholders' perceptions about pelleted compost in Northwestern Italy. Sustainability 2018, 10, 2028. [CrossRef]

14. Wang, Q.; Awasthi, M.K.; Zhao, J.; Ren, X.; Li, R.; Wang, Z.; Wang, M.; Zhang, Z. Improvement of pig manure compost lignocellulose degradation, organic matter humification and compost quality with medical stone. Bioresour. Technol. 2017, 243, 771-777. [CrossRef]

15. Farrell, M.; Jones, D.L. Critical evaluation of municipal solid waste composting and potential compost markets. Bioresour. Technol. 2009, 100, 4301-4310. [CrossRef]

16. Zhu, K.; Christel, W.; Bruun, S.; Jensen, L.S. The different effects of applying fresh, composted or charred manure on soil $\mathrm{N}_{2} \mathrm{O}$ emissions. Soil Biol. Biochem. 2014, 74, 61-69. [CrossRef]

17. Alemi, H.; Kianmehr, M.H.; Borghaee, A.M. Effect of pellet processing of fertilization on slow-release nitrogen in soil. Asian J. Plant Sci. 2010, 9, 74-80. [CrossRef]

18. Gil, M.V.; Carballo, M.T.; Calvo, L.F. Fertilization of maize with compost from cattle manure supplemented with additional mineral nutrients. Waste Manag. 2008, 28, 1432-1440. [CrossRef]

19. Pampuro, N.; Bertora, C.; Sacco, D.; Dinuccio, E.; Grignani, C.; Balsari, P.; Cavallo, E.; Bernal, M.P. Fertilizer value and greenhouse gas emissions from solid fraction pig slurry compost pellets. J. Agric. Sci. 2017, 155, 1646-1658. [CrossRef]

20. Pampuro, N.; Dinuccio, E.; Balsari, P.; Cavallo, E. Evaluation of two composting strategies for making pig slurry solid fraction suitable for pelletizing. Atmos. Pollut. Res. 2016, 7, 288-293. [CrossRef]

21. Subedi, R.; Taupe, N.; Pelissetti, S.; Petruzzelli, L.; Bertora, C.; Leahy, J.J.; Grignani, C. Greenhouse gas emissions and soil properties following amendment with manure-derived biochars: Influence of pyrolysis temperature and feedstock type. $J$. Environ. Manag. 2016, 166, 73-83. [CrossRef]

22. Kumar, R.R.; Park, B.J.; Cho, J.Y. Application and Environmental Risk of Livestock Manure. J. Korean Soc. Appl. Biol. Chem. 2013, 56, 497-503. [CrossRef]

23. Gurtler, J.B.; Doxle, M.P.; Erickson, M.C.; Jiang, X.; Millner, P.; Sharma, M. Composting to inactivate Foodborne pathogens for crop soil application: A review. J. Food Prot. 2018, 81, 1821-1837. [CrossRef]

24. Shepherd, M.W.J.; Liang, P.; Jiang, X.; Doyle, M.P.; Erickson, M.C. Fate of Escherichia coli O157:H7 during on-farm dairy manure-based composting. J. Food Prot. 2007, 70, 2708-2716. [CrossRef]

25. Barberg, A.E.; Endres, M.I.; Salfer, J.A.; Reneau, J.K. Performance, health and well-being of dairy cows in an alternative housing system in Minnesota. J. Dairy Sci. 2007, 90, 1575-1583. [CrossRef]

26. Leso, L.; Uberti, M.; Wasseem, M.; Barbari, M. A survey on Italian compost dairy barns. J. Agric. Eng. 2013, 44, $203-207$.

27. Klaas, I.C.; Bjerg, B.S. Compost barns-An alternative housing system for dairy cows? Anim. Sci. Rev. 2011, 145, 145-153. [CrossRef] 
28. Klopčič, M.; Galama, P.; Kuipers, A. Inovacije v Sistemih Nastanitve in Managementa za Krave Molznice [Innovation in Housing and Management Systems for Dairy Cows]. In Proceedings of the 28th International Scientific Symposium on Nutrition of Farm Animals [being] Zadravec-Erjavec Days, Radenci, Slovenia, 7-8 November 2019; Čeh, T., Kapun, S., Eds.; Kmetijsko Gozdarska Zbornica Slovenije, Kmetijsko Gozdarski Zavod: Murska Sobota, Slovenia, 2019; pp. 95-100.

29. Galama, P.; Ouweltjes, W.; Endres, M.; Sprecher, J.R.; Leso, L.; Kuipers, A.; Klopčič, M. Future of housing for dairy cattle: Symposium review. J. Dairy Sci. 2020, 103, 5759-5772. [CrossRef]

30. Eggerth, L.L.; Diaz, L.F.; Chang, M.T.F.; Iseppi, L. Chapter 12 Marketing of composts. Waste Manag. $2007,8,325-355$.

31. Wilson, P.; Lewis, M.; Ackroyd, J. Farm Business Innovation, Cooperation and Performance; Rural Business Research: Defra, UK, $2014 ;$ p. 69.

32. Ajzen, I.; Fishbein, M. Belief, Attitude, Intention and Behavior: An Introduction to Theory and Research; Addison Wesley: Boston, MA, USA, 1975; p. 573.

33. Wachenheim, C.J.; Rathge, R.W. Societal Perceptions of Agriculture. In Agribusiness E Applied Economics Report 23541; North Dakota State University: Farfo, SD, USA, 2000; p. 41.

34. Lappo, A.; Bjørndal, T.; Fernández-Polanco, J.; Lem, A. Consumers' concerns and external drivers in food markets. FAO Fish Aquac. Circ. 2015, 1102. Available online: http://www.fao.org/3/i4939e/i4939e.pdf (accessed on 30 April 2021).

35. Cummins, A.; Olynk Widmar, N.; Croney, C.; Fulton, J. Perceptions of Animal Agriculture and Meat Products: Spotlights on Indiana, Illinois, Michigan, Ohio and Wisconsin; Center for Animal Welfare Science, Purdue University: West Lafayette, IN, USA, $2015 ;$ p. 26.

36. Frewer, L.J.; Kole, A.; van de Kroon, S.M.; de Lauwere, C. Consumer attitudes towards the development of animal-friendly husbandry systems. J. Agric. Environ. Ethics 2005, 18, 345-367. [CrossRef]

37. Vanhonacker, F.; Verbeke, W. Public and Consumer Policies for Higher Welfare Food Products: Challenges and Opportunities. J. Agric. Environ. Ethics 2014, 27, 153-171. [CrossRef]

38. Alonso, M.E.; González-Montaña, J.R.; Lomillos, J.M. Consumers' Concerns and Perceptions of Farm Animal Welfare. Animals 2020, 10, 385. [CrossRef] [PubMed]

39. Nowotny, H. The Cunning of Uncertainty; Polity Press: Cambridge, MA, USA, 2016.

40. Jervis, M.G.; Drake, M.A. The use of qualitative research methods in quantitative science: A review. J. Sens. Stud. 2014, 29, 234-247. [CrossRef]

41. Klopčič, M.; Kuipers, A.; Malak-Rawlikowska, A.; Stalgiene, A.; Ule, A.; Erjavec, K. Dairy farmers' strategies in four European countries before and after abolition of the milk quota. Land Use Policy 2019, 88, 104169. [CrossRef]

42. European Commission. Special Eurobarometer 442 on Attitudes of Europeans towards Animal Welfare. Available online: https:/ / ec.europa.eu/commfrontoffice/publicopinionmobile/index.cfm/Survey/getSurveyDetail/surveyKy/2096 (accessed on 20 November 2020).

43. European Commission. Special Eurobarometer 354 on Food Related Risk. Available online: https:/ / ec.europa.eu/commfrontoffice/ publicopinion/index.cfm/Survey/getSurveyDetail/instruments/SPECIAL/surveyKy/1476 (accessed on 16 January 2021).

44. Leso, L.; Barbari, M.; Lopes, M.A.; Damasceno, F.A.; Galama, P.; Taraba, J.L.; Kuipers, A. Invited review: Compost bedded-pack barns for dairy cows. J. Dairy Sci. 2020, 103, 1072-1099. [CrossRef]

45. Food Patterns and Dietary Recommendations in Spain, France and Sweden. Available online: https:/ /livewellforlife.eu/wpcontent/uploads/2012/04/LW_A4-Food-Rept_Update_final.pdf (accessed on 30 September 2020).

46. Valicon Ogledalo Slovenije 2014-2018 (Valicon Mirror Slovenia 2014-2018). Available online: https:/ / skupnostobcin.si/wpcontent/uploads /2018/04/raziskava-valicon-ogledalo-slovenije-2018.pdf (accessed on 2 October 2020).

47. Godina, V. Zablode Postsocializma (The Delusions of Postsocialism); Beletrina: Ljubljana, Slovenia, 2016; p. 286.

48. Klopčič, M.; Slokan, P.; Erjavec, K. Consumer preference for nutrition and health claims: A multi-methodological approach. Food Qual. Prefer. 2020, 82, 103863. [CrossRef]

49. Beardsworth, A.; Bryman, A.; Keil, T.; Goode, J.; Haslam, C.; Lancashire, E. Women, men and food: The significance of gender for nutritional attitudes and choices. Br. Food J. 2002, 104, 470-491. [CrossRef]

50. Kol, O.; Lissitsa, S. Generation X vs. Generation Y-A Decade of online shopping. J. Retail. Consum. Serv. 2016, 31, 304-312.

51. Beneficial Uses of Manure and Environmental Protection. Available online: https://www.ncba.org/CMDocs/BeefUSA/Media/ Beneficial\%20Uses\%20of\%20Manure\%20FINAL\%20Aug2015.pdf (accessed on 11 January 2021). 